\title{
Some Constitutional and Legal Aspects in Society Political System Structure
}

\author{
Nazira Kolsarieva1, Erkin Duisenov ${ }^{2}$, Nurgul Atabekova ${ }^{3}$, Niiazbek Pazylov", \\ Tolgonai Uraimova ${ }^{5}$, Ravil Mazitov ${ }^{4}$, Zhypargul Abdullaeva ${ }^{*}$ []
}

${ }^{1}$ Department of Theory and History of Government Law, Osh State Juridical Institute, Osh, Kyrgyzstan

${ }^{2}$ Constitutional, International Law and Customs Department, Eurasian Law Academy named after D.A. Konaev, Almaty,

Kazakhstan

${ }^{3}$ Department of Constitutional and Municipal Law of the Kyrgyz State Law University, Bishkek, Kyrgyzstan

${ }^{4}$ Department of Civil Law and Procedure, Osh State Juridical Institute, Osh, Kyrgyzstan

${ }^{5}$ Department of Jurisprudence, Osh State Law Institute, Osh, Kyrgyzstan

${ }^{6}$ Science and Research Department, Osh State University, Osh, Kyrgyzstan

Email: *jypar.science@oshsu.kg

How to cite this paper: Kolsarieva, N., Duisenov, E., Atabekova, N., Pazylov, N., Uraimova, T., Mazitov, R., \& Abdullaeva, Z. (2021). Some Constitutional and Legal Aspects in Society Political System Structure. Open Journal of Social Sciences, 9, 31-41. https://doi.org/10.4236/jss.2021.99003

Received: August 3, 2021

Accepted: August 29, 2021

Published: September 1, 2021

Copyright $\odot 2021$ by author(s) and Scientific Research Publishing Inc. This work is licensed under the Creative Commons Attribution International License (CC BY 4.0).

http://creativecommons.org/licenses/by/4.0/ (c) (i) Open Access

\begin{abstract}
The article presents some constitutional and legal aspects analysis in understanding the structure of a political system in society. Idea of a political system in demand and science was previously emphasized on understanding it as an analogue of a political organization, i.e. its institutional side and tools with gradual recognition and updating of methodological guidelines. It is also recognized that the variety of approaches and the complexity of phenomenon determines the variability in the interpretation of the definitions formed in the article for several reasons. It is noted that in political science, in the post-Soviet format, there is a noticeable differentiation with existing concept legal interpretations. The specificity of constitutional law has led to a relatively small appeal to the specified problems, which are based on the government interactions with other elements mediated by constitutional law using system analysis. Political system is analyzed in the presence of multitude subjects of political relations together reflecting entire spectrum of its constituent elements; constitutional and legal science methods with concrete historical approach of various groups in society were used. Attention is drawn to a historical aspect of the presidency institution formation, as well as the controversy about the system of government in Kyrgyzstan.
\end{abstract}

\section{Keywords}

Constitution, Society Political System, Government Parties, Power, Integration of Policy Forms Implementation, Constitutional and Legal Concepts, Government Form, Presidency Institution 


\section{Introduction}

The government, functioning in a social environment, actualizes the expansion of knowledge about correlation relationships and their expression in a system of new concepts and coordinates from the standpoint of scientific methods of analysis and synthesis, legal comparative studies, historical and legal, systemic, structural-functional and other methods of scientific knowledge of social reality. Central Asia and its socio-political realities interested many scientists, although political perspective of their use follow-up was not a priority, their contribution should not be underestimated in understanding this problem (Alaev et al., 2007: p. 16).

It is undoubtedly true that the structure of political power of the nature of power, its constituent components rest on a complex system that covers the processes of development, formation and functioning of a set of socio-political institutions in Kyrgyzstan, which became the subject of the presented analysis.

Also, the controversy about the system of government seems to be special and significant. So, according to several leading scientists-constitutionalists, the optimal system can be considered a system where the government, headed by the prime minister, appointed and controlled by the parliament, functions independently (Chernobel, 2017: p. 85).

According to other authors, the system that assumes the president and the prime minister in the constitutional design can lead to disproportions in the ratio of the competencies of these bodies (Sakharov, 2016: p. 110).

Such scientific polemics about the form of government in modern Kyrgyzstan are actualized by multiple additions and changes to the Basic Law of the Kyrgyz Republic, and, therefore, requires an updated perception from the standpoint of the theory of constitutional law, which also stipulates scientific interest in constitutional reforms, their conceptuality, frequency, socio-political effectiveness and justification.

Of course, one of the most significant is the question of the form of government in the Constitution of the Kyrgyz Republic, 1993. In the scientific literature, the essence of conditions and prerequisites for a transition period in the Kyrgyz Republic was dictated by the need for a strong executive power, which gave rise to an active scientific discourse about which form of government would create the most optimal format existence, which argued the position of the presidential form of government (Amanbaev \& Aitieva, 2009).

Also, along with an understanding of the nature of political power which is formed based on the integration of many individuals and activities will in various structures, based on the relationship of individuals, personifying power, and organizations by realized power (Napalkova, 2020: p. 35); information about the phenomena related to political and state life reveals an urgent need for their differentiation. Moreover, to denote the sum of these phenomena, the concept of "politics" is vague, while the category of "government" covers only partly the entire palette of phenomena (Temirbekova, 2020).

In law science, more active use of the concept is also actualized, which can re- 
flect total relationship in generalized development of the category "political system in society" as a stable form of human relations, through which authoritative decisions for a given society are made and implemented (Saitbekov, 2016: p. 205). One of the issues that led to the analysis undertaken was an attempt from the standpoint of constitutional and legal science to present some aspects of their implementation in Kyrgyzstan (Artykbaev et al., 2009).

The idea of a political system as it is known was not adapted in constitutional and legal science during the time of the USSR, and focused on its translation, as an analogue of a political organization, i.e. its institutional sphere, as well as in the context of the toolkit of prevailing propaganda. The political system of society is determined as a complex set of government institutions, political parties, public organizations within the political life of society in government and public authority (Bondar, 2012: p. 59).

\section{Research Methods and Materials}

In the process of analyzing the category "political system" in a new methodological key, the presence of a multitude subjects of political relations is recognized, which together reflect the entire spectrum of its constituent elements. This list logically includes parties, public associations, movements and trade unions, etc.

Research results obtained from constitutional and legal science, using a concrete historical approach (Lappo-Danilevsky, 2013: p. 48) linking with the presence of various groups in society; a set of norms, ideas, institutions and actions based on organizing power, the relationship between citizens and the government (Marchenko, 2017: p. 184).

\section{Results and Discussions}

\subsection{Political System Definitions}

Various attempts based on the analysis of the elements of the system have led to many of its interpretations. Shubin V.A. proceeds from the fact that "these are political institutions, organizations, theories that exist in society, reflecting certain interests" (Burlatsky, 1978: p. 5).

Tikhomirov Yu.A. noted that "The political system is the integration of forms of implementation of politics and power and regulation of socio-political activity in the interests of the ruling class" (Shubin, 2018: p. 4). Of course, it is worth noting that the complexity of developing the concept of a political system was linked to the confrontation and dichotomy of social systems. The system of power relations was defined as a social mechanism of power by the people.

In the legal science of that period, the political system and the mechanism of power were identified. B.N. Topornin proceeds from the position: "The political system is a complex of government and public organizations, when the people manage the affairs of society" (Tikhomirov, 2015: p. 25). Other authors, I.P. Ilyinsky and N.V. Chernogolovkin admitted: "The political system is a complex of interacting means of organizations for managing society (Topornin, 2014: p. 23). 
In addition to Marxist ideas about the political system, for a deep understanding of the essence of this phenomenon, it is important to recognize nonMarxist interpretations that imply variability of interpretation, with a focus on the institutional aspect, where the basis is not its functions, but structure, etc. (Ilyinsky \& Chernogolovkin, 1991: p. 12).

D. Easton's ideas can be recognized as the leading direction in socio-humanities. He based his theoretical views on the idea of it as one of the varieties of systems that form the environment, the differential feature of which is the correlation between the subjects of political relations. Emphasizing the imperious nature and the ability to make authoritarian decisions, D. Easton calls it a "decisionmaking machine" that can exist in any society where individuals cooperate or enter into conflicts processes in resolving these issues (Kozlova, 1978: p. 343).

\subsection{Government Power Characteristics}

Recognizing the achievements in political science as a science of the post-Soviet format, there is a clear differentiation with the existing legal interpretations of a concept that is not studied so widely, which is mediated by many circumstances.

For example, the specificity of constitutional law has led to a relatively small appeal to the specified problems, which are based on the government interactions with other elements, that is, they are mediated by constitutional law using system analysis, which also determines the specifics of legal and political science problems and is correlated with a system of government bodies, different in meaning, structure and competence.

In this regard, S.A. Komarov and A.V. Malko distinguished by the following determinations:

1) The institutional approach is based on the analysis of structural and formal legal aspects;

2) The functional aspect, considering the latter from the standpoint of the specifics of the political process and the implementation of the current regime;

3) Regulatory, reflecting functioning based on normative regulation;

4) Ideological, as a phenomenon of views and ideas on the problem of the existence of a political system and building a specific theory.

The most actively encountered definitions appear as certain vectors, which also need to be distinguished:

1) "Subjects of the struggle for participation in the government affairs";

2) "Strong-willed relations in government bodies, in the context of the exercise of power" (Demidov, 2012: p. 51);

3) "Interacting bodies of the government, associations and institutions through which the people participate in government" (Spiridonov, 2014: p. 22);

4) "Form organizations, institutions in the struggle for power, its retention and functioning" (Gorbatyuk \& Kuchinsky, 2016: p. 74), etc.

It is important to recognize that the democratic political and legal foundations of the political system are characterized by the sum of the principles and norms of the organization, within the framework in which power was managed. Politi- 
cal power in the government, as is known from the course of the theory of law, is expressed at several levels, which it is advisable to highlight:

1) In the form of government power, due to the primacy of the provision on the implementation of the will of the people, serving as the source and social base of power;

2) Power manages by the government apparatus, which implies the presence of various bodies, which explains the objectified content of the power mechanism.

Consequently, the recognition of the methodological significance and theoretical understanding of political power as a basic component of the political system determines the institutional structuring of the system, as well as its constituent institutions, and, above all, the government.

\section{Conceptual Decisions in Political System}

This understanding of the institutional form of government is predetermined by conceptual decisions and the direct exercise of power, which are reflected in principles with norms and are subsequently constituted, acquiring their meanings. It naturally follows understanding about the essence of political and legal concept of power in the government based on the idea of separation of powers, its consolidation through a system of "checks and balances." Financial regulation in the broadest sense of the word includes fiscal and monetary policy, the object of which is the application in the budget, public debt, tax and banking systems, the market, credit relations (Zhaparov \& Cholbaeva, 2016: p. 88).

Undoubtedly, the concept of separation of powers, in fact, "dictates" the delineation of the functions of the government and its institutions, in other words, it implies a clear fixation of government powers and functions between government bodies to prevent the concentration of power in one body.

In the context of the analysis, it is advisable to generalize the positions and develop a working definition, meaning by the latter, the constitutionally enshrined set of government bodies and non-government institutions that guarantee the participation of the people in the management of government affairs. It can be assumed that the formation of a political system correlates with the presence of characteristic properties in political relations (Mikhailenok et al., 2020: p. 207), which must be also highlighted as:

1) Correlated connections of elements;

2) The optimality of political relations;

3) The presence of cultural grounds, implying a commonality of values and beliefs;

4) Mobilization of elements for external influences.

In the context of analysis, it is logical to pay attention to the so-called progressive type of political system, which is formed as a result of the system's ability to satisfy its interests.

It is also possible to recognize the special theoretical and practical significance of the correlation of the political system of society and the government. There- 
fore, without belittling the role of the government in the system of democratic organizations, it should be recognized that the concept of a leading subject in the structure of the political system is recognized as a person. Such a government is achievable when the system is built on the priority of the rule of law.

In this sense, the Constitution of the Kyrgyz Republic has approved the government as democratic, legal and social, the highest values of which is a person, his life, rights and freedoms, is a harbinger of the achievement of such values.

\section{Parties in the Political System Structure}

Parties are the supreme important components in the structure of the political system, as they provide necessary communication between the government and society, between the government and existing interest groups in society (Avju, 2013: p. 85). According to Zaslavsky S. E., party is "one of the institutions participating in the power struggle, ensuring the circulation of the political elite" (Lazareva, 2015: p. 5).

In the theory of constitutional and legal science, several theoretical developments substantiated the parties' objectified appointment. Therefore, summarizing the various positions, we can highlight the main functions of the parties:

1) They act as a means of political self-identification of an individual, the realization of rights through association in a party;

2) Contribute to the development of the main directions of state policy;

3) Developing alternatives for getting out of crises;

4) Promote the training of personnel, from among whom the ruling elite will subsequently be formed.

Of course, it is advisable to recognize the uniqueness of the experience of forming the political system of the Kyrgyz Republic. Thus, the distribution of powers for the formation of executive power between the President and the JK of the Kyrgyz Republic in the Constitution of the Kyrgyz Republic of 1993 is characteristic of a mixed form of government. Meanwhile, even the presence of broad powers of the JK KR the specified form of government in 1993-1996 and it is logical to recognize it as semi-parliamentary (Zaslavsky, 2012: p. 12).

For example, according to the 1993 Constitution, the President of the Kyrgyz Republic had some powers:

- Determines the structure of the Government of the KR and submits it for approval by the Jogorku Kenesh (JK) KR;

- Appoints, with the consent of the JK KR, the Prime Minister of the KR;

- Appoints members of the Government on the proposal of the Prime Minister and with the consent of the JK KR.

\section{Constitutional Norms}

It seems to us that the specified terms of reference partly coincide with the powers of the President of the Kyrgyz Republic in the context of the new edition of the Kyrgyz Republic Ministry of Justice (2021). The Constitution of the Kyrgyz Republic of 1993 set the vector for strengthening the presidential power, which 
gradually strengthened the tendencies, subsequently led to authoritarian power, significantly affecting the entire system of public administration.

Later, a referendum in 1996, amended the Constitution of the Kyrgyz Republic, expanding the powers of the president by reducing them in the JK of the $\mathrm{Kyr}$ gyz Republic.

Thus, innovations in the legal status of the head of government were implemented in the following constitutional norms in article 42 (Kyrgyz Republic Ministry of Justice, 2021: p. 1).

1) The president "is the head of government, the highest official", "a symbol of the unity of the people and government power";

2) Supremacy of the power of the people is ensured by the elected head of government who is the president;

3) The president "determines the main directions of the government policy", "ensures the unity and continuity of power, the coordinated functioning and interaction of government bodies."

The opinion that the results of the 1996 referendum significantly strengthened the president's power against the background of the decrease in the role of the $\mathrm{JK}$ and the "pulling together of new structures to the center of power" can be recognized as correct (Chotaev, 2019: p. 24).

It should be admitted about amendments to the Constitution of the Kyrgyz Republic in 1994, 1996, 1998, 2003 contributed to the establishment of an authoritarian regime. In the wording of the Constitution of the Kyrgyz Republic (October 21, 2007), the President, having usurped power, significantly influenced the formation of legislative power, the election of deputies of the Jogorku Kenesh of the Kyrgyz Republic. By 2008, a super-presidential government was finally formed in the Kyrgyz Republic, and the so-called informal governing structures stood over the official government institutions.

The super-presidential regime was characterized by such characteristics as clannishness, criminalization of power, suppression of freedom of speech and persecution of the opposition, which led to the tragic events of April 7, 2010. Thus, the new Provisional Government proclaimed the main goal of reforming the political system, building a parliamentary form of government in the Kyrgyz Republic (Ashirov, 2017: p. 80).

It should be recognized that the Constitution of the Kyrgyz Republic (as revised in 2010) established legal guarantees to limit the influence of the President of the Kyrgyz Republic on the branches of government. The constitutional reform led to the establishment of a parliamentary-presidential form of government. The powers of the head of state were significantly reduced, which was assigned representative functions.

The Kyrgyz Republic President ensures the coordinated functioning of the branches of government, acts as a kind of arbiter. Often, in government with a parliamentary form of government, the president is not elected by the people. In the Kyrgyz Republic, the president, according to the above conditions elected by public vote, which means that there is a wide range of powers, in contrast to presi- 
dent, who is elected by the parliament.

The innovations were affected by the fact that the President of the Kyrgyz Republic was elected for 6 years, and the fact that the same person cannot be elected President twice.

On October 30, 2011, regular elections of the President of the Kyrgyz Republic were held, A. Atambaev was elected the head of government.

It can be assumed that limiting the role of the President to a symbol of power under the current Constitution of the Kyrgyz Republic in conditions of political turbulence is fraught with serious social upheavals and cataclysms. In fact, in Kyrgyzstan during that historical period, a mixed parliamentary-presidential form of government was implemented (Zhumaliev \& Ozhukeeva, 2018: p. 35).

In general, a stable political system has been formed in Kyrgyzstan, where its components follow the path of further democratization. In the context of the analysis, it is advisable to dwell on each of its structural components.

It can be recognized that the Kyrgyz parties in the last decade of modern history are actively using their protest potential using various forms of participation (elections, campaigning, holding meetings and demonstrations) (Iskakova, 2017: p. 57).

In this context, the government must guarantee the realization of rights, since this will help stabilize the situation and consider the interests of all social groups. In general, it can be recognized that the process of active parthenogenesis continues in the Kyrgyz Republic.

\section{Public Associations and Movements}

These are voluntary associations created to meet a wide range of needs arising as a result of the development of processes in society and created based on a commonality of interests and specified goals. Acute social problems that arose in the first years of Kyrgyzstan's independence caused the emergence in formation of humanitarian non-government organizations (NGOs), whose activities aimed at distributing food aid to low-income groups of the population (Bektanova, 2016: p. 97).

In Kyrgyzstan, public movements (including opposition ones), international NGOs, foundations, academics, environmental associations, associations for the protection of consumer rights, etc. are currently operating in Kyrgyzstan. The Kyrgyz society also recognizes the leading role of human rights organizations as a significant indicator of the achievements of democracy (Naimanbaev, 2011: p. 12). Economic situation has a stronger effect on the development of political processes in Central Asian countries, exacerbating competition between elites for resources, inability to address acute regional problems as well as worsening social conditions (Krivopalov, 2016: p. 19).

Trade unions are associations designed to protect the interests of workers. They are autonomous, and operate voluntarily and community of interests and protect the labor and other rights of their members. 
Of course, public control exercised by trade unions is aimed at ensuring rights and is coordinated at the level of correctness of the application of legislation. However, in general, trade unions and their movements are not so active at the current stage, which is probably due to an active increase in unemployment, labor migration outside the Kyrgyz Republic, as well as the crisis caused by the COVID-19 pandemic, which has not yet become the subject of separate studies.

Movements in an organizational format are non-centralized, without fixed membership, where there is a clear tendency for a selection and discipline system that optimally combines freedom of choice with the simultaneous exercise of rights.

However, according to the expert opinion of several domestic researchers, at the current moment, the movements are also not so active. Many important problems are known to be solved through the efforts of ecological movements, the democratization of society, etc.

\section{Conclusion}

Summarizing the results of the analysis, several conclusions can be highlighted:

1) In the current reality in the Kyrgyz Republic, parties, public associations, trade unions, movements act as constituent elements of the political system;

2) Legislative regulation of the procedure for the formation of the entire spectrum of constituent elements is mediated by their public law status;

3) Various interpretations of the political system from the standpoint of both the Soviet period and its modern understanding are presented;

4) Also presented is the differentiation of the theoretical understanding of the political system from the standpoint of non-Marxist views, formed at a later stage;

5) In the Kyrgyz Republic there is an active process of institutionalization of public institutions corresponding to strategic cooperation with government agencies;

6) The idea is substantiated that democratic values must be developed in society in the context of a new form of organization of the political system, which guarantees an increase in the standard of living mediated by an optimally functioning system of institutions;

7) The institution of the Presidency in the Kyrgyz Republic for 30 years since the proclamation of sovereignty, regardless of the form of government and political regime, has occupied an important political place in the system of government bodies.

\section{Conflicts of Interest}

The authors declare no conflicts of interest regarding the publication of this paper.

\section{References}

Alaev, L. B., Akhmedov, V. M., Bekkin, R. I., Belokrenitsky, V. Y., Volodin, A. G., Voskresensky, A. D., Gudoshnikov, L. M., Denisov, V. I., Dontsov, V. E., Druzhilovsky, S. B., Emelyanov, A. L., Efimova, L. M., Kudryashova, I. V., Laletin, Y. P., Luzyanin, S. G., Lunev, S. 
I., Molodyakova, E. V., Sapronova, M. A., Starostin, C. B., Starostin, P. B., Strezhneva, M. V., Streltsov, D. V., Churilina, T. A., Epstein, A. D., \& Voskresensky, A.D. (2007). Political Systems and Political Cultures of the East (2nd ed., 829 p). East-West.

Amanbaev, B. A., \& Aitieva, S. Z. (2009). To the Question of Political Modernization and Transformation: Transition to Democracy. Science and New Technologies, 1-2, 238-241.

Artykbaev, A., Amanbaev, B., \& Aitieva, S. Z. (2009). Models of Political Development of the Post-Soviet Republic. Science and New Technologies, 1-2, 137-139.

Ashirov, Z. T. (2017). Government-Political Regime in the Kyrgyz Republic and the Stages of the Formation of the President. Institution. Bulletin of the South Ural State University, $17,80-85$.

Avju, S. A. (2013). Fragmentation of the System of Political Parties in Kyrgyzstan. Central Asia and the Caucasus, 16, 84-101.

Bektanova, A. K. (2016). Genesis of the Civil Sector in Kyrgyzstan. Problems of Modern Science and Education, 3, 97-101.

Bondar, N. N. (2012). Political System: Concept, Essence, Structure, Functions. Society and Law, 5, 59-61.

Burlatsky, F. M. (1978). Our Time Political Systems (277 p).

Chernobel, G. T. (2017). The Constitution as the Basic Law of the State in the Value Dimen$\operatorname{sion}(85 \mathrm{p})$.

Chotaev, Z. J. (2019). Parliamentary Form of Government in Kyrgyzstan (24 p).

Demidov, A. I. (2012). The Political System of Society and the Government (772 p).

Gorbatyuk, N. A., \& Kuchinsky, V. A. (2016). General Theory of Law: Basic Concepts and Logical Schemes (150 p).

Ilyinsky, I. P., \& Chernogolovkin, N. V. (1991). The Political System of Society. Soviet State and Law, 1, 35-37.

Iskakova, G. T. (2017). Elections and Democracy in Kyrgyzstan: Constitutional Design of Presidential-Parliamentary Relations (57 p).

Kozlova, E. I. (1978). Soviet Government Law (439 p).

Krivopalov, A. A. (2016). From Turkestan to Central Asia: The Political Future of the Region (114 p). Center for the Study of a Crisis Society.

Kyrgyz Republic Ministry of Justice (2021). Kyrgyz Republic Constitution. URL (Last Checked on August 2, 2021). http://cbd.minjust.gov.kg/act/view/ru-ru/202913

Lappo-Danilevsky, A. S. (2013). History Methodology. Introduction. Journal of Sociology and Social Anthropology, 16, 44-58.

Lazareva, V. V. (2015). General Theory of Law and Government (517 p).

Marchenko, M. N. (2017). The Political System of Modern Bourgeois Society (2nd ed., 312 p).

Mikhailenok, O. M., Malysheva, G. A., Shchenina, O. G., Zelenko, B. I., Voronkova, O. A., Mitrofanova, A. V., Shimanskaya, E. S., Brega, A. V., Nikovskaya, L. I. I., Lyublinsky, V. V., Makushina, L. V., \& Nazarenko, A. V. (2020). Social Reality and Political Relations in the Context of the Network Paradigm: Problems and Research Prospects. Social and Humanitarian Knowledge, 3, 201-241.

Naimanbaev, A. B. (2011). Development of the Legislation of the Kyrgyz Republic in Modern Conditions: Theoretical Issues: Abstract of a Dissertation. Juridical Sciences, Moscow, $12 \mathrm{p}$.

Napalkova, I. G. (2020). The Political Nature of State Power. Bulletin of the Faculty of Law 
of the Southern Federal University, 7, 34-39.

Saitbekov, A. M. (2016). The Concept of the Political System of Society. Science Symbol, 3-4, 205-208.

Sakharov, N. A. (2016). The Institution of the Presidency in the Modern World (2nd ed., 110 p). Jurid. Lit.

Shubin, V. A. (2018). The Political System of State-Monopoly Capitalism (250 p).

Spiridonov, L. I. (2014). Theory of Government and Law (280 p).

Temirbekova, A. T. (2020). Change in the Kyrgyzstan Society Political System to the Side of Formation of the Parliamentary Republic. Bulletin of the Diplomatic Academy of the Ministry of Foreign Affairs of the Kyrgyz Republic Named after Kazy Dikambayev, 13, 157-169.

Tikhomirov, Y. A. (2015). The Development of Political Systems in the Modern World(315 p.).

Topornin, B. N. (2014). Soviet Political System (2nd ed., 320 p).

Zaslavsky, C. E. (2012). Political Parties of Russia: Problems of Institutionalization (300 p.).

Zhaparov, G. D., \& Cholbaeva, S. D. (2016). Conceptual Framework for Regulating the State Budget of the Kyrgyz Republic. Science, Technology and Education, 2, 88-93.

Zhumaliev, K., \& Ozhukeeva, T. (2018). XXI Century: Institute of Presidency in the Kyrgyz Republic (35 p). 